\title{
Changing nuclear fortunes
}

News last week transformed uncertainty surrounding the reprocessing of nuclear fuel in Britain into certainty. For the Dragon reactor, the reverse seemed to occur. Allan Piper and Roger Woodham report

After several months' delay British Nuclear Fuels Ltd (BNFL) has obtained Government approval for plans to import and reprocess 6,000 tonnes of foreign nuclear fuel. The goahead clears the way for an early settlement of the contract for BNFL to handle up to 4,000 tonnes of material from Japan's new generation of light water reactors at its Windscale plant in Cumbria. But further delays are expected following French moves to capture part of the deal, which is worth as much as $£ 600$ millions over the decade following 1979.

Mr Con Allday, BNFL's managing director, has indicated that the head of the French reprocessing organisation Compagnie Generale des Matieres Nucleaires (CGMN) may accompany him to Japan later this month. The French intervention, made possible by their involvement in a tripartite reprocessing alliance with Britain and West Germany, could mean the loss to BNFL of up to half of the Japanese contract.

Final settlement of the Japanese deal, which has aroused some controversy in the UK, has been delayed by a Government investigation into the issue. Granting Government approval last week, the Energy Secretary, $\mathrm{Mr}$ Anthony Wedgwood Benn, said that the Government had "given full consideration to the safety and environmental implications of accepting more work of this kind, taking account particularly of the views which have been expressed in the recent extensive public discussion of the question".

It is now clear that all waste, whether reprocessed or not, will eventually return to Japan, and that the deal does not contravene the Non-Proliferation Treaty. In further contracts clients must accept a break clause freeing BNFL if residual waste cannot be treated for safe return in a glassificd form.

BNFL have already expressed confidence that successful completion of the Japanese negotiations will bring in other orders, and Iran, Italy, Spain, Sweden and West Germany have been unofficially mentioned in this connection. To meet projections for oxide reprocessing by 1990 BNFL plan to invest $£ 900$ millions in two new reprocessing plants at Windscale.

Meanwhile, the moribund Dragon High Temperature Reactor Project continues to attract attention. Whatever the politicians in Brussels may decide about a data retrieval programme to get the most out of the Dragon project, a sum of about $£ 700,000$ has already been committed hy other interested parties to this end. The German nuclear research centre, KFA Jülich, has chipped in $£ 480,000$ to make sure that all the information it needs for its work on high temperature reactors is wrung out of the project, and even the European Commission and the United States Energy Research a nd Development Administration (which eventually declined at the end of last year to help keep the project afloat) are contributing to a brief continuation of the programme concerning the effects of helium in the primary cooling circuit on the metals used there. This work is likely to continue to the end of the year and involves carrying on existing Dragon contracts with the Norwegian research centre CIIR and the Fiat company in Turin.

Apart from the $£ 130,000$ which it is making available for this venture, KFA Jülich is also providing $£ 350,000$ towards a seemly winding-up of the work at Dragon on fuel elements, in which it has a particular interest. This will involve what remains of the Dragon staff in post-irradiation experiments on the test fuel, some of which is still in the reactor.

The German research centre does, however, stand to recoup that $£ 350,000$ if a more comprehensive plan put up by the European Commission survives the Brussels obstacle course. The commission is suggesting a data retrieval programme costing $£ 1.16$ million, of which it would pick up the tab for $90 \%$ - the assumption being that some of the smaller countries that have participated in Dragon would stump up the remainder, and that the UK Atomic Energy Authority would contribute nothing.

The indications are, however, that the polanisation of political views in the Council of Ministers is such that even this-an expenditure of some $2 \%$ of the total amount of money spent on Dragon since its inception in 1959 to see the project decently buried-is by no means certain to be acceptable. And, in addition, some of the smaller countries associated with the project have simply given up in disgust.

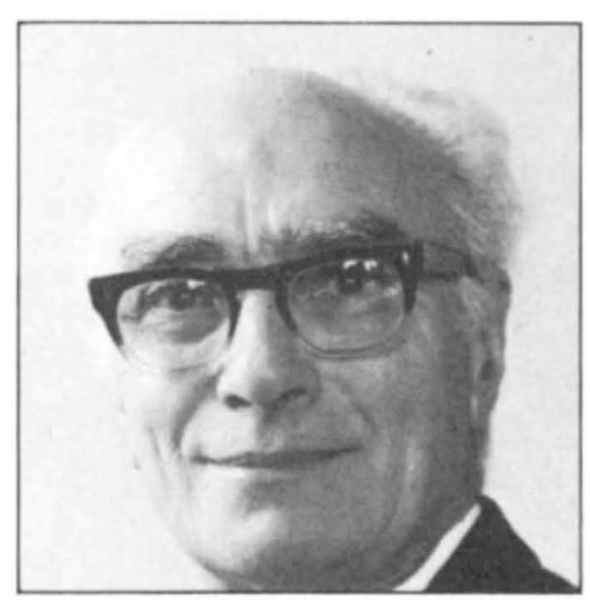

Chairing ASTEC review: Dr Louis Matheson

(ASTEC), which was under very real threat of abolition or absorption within the public service structure. To the
Peter Pockley reports from Sydney on the latest developments affecting Australia's scientific community three months into the new administration

Shelteren from the blaze of publicity surrounding the activities of the Federal politicians as they jockeyed for position before the opening of the new parliament, Australian scientists have been working behind the scenes to protect their interests. During January and February, the Prime Minister, $\mathrm{Mr}$ Malcolm Fraser, was busy putting the axe into a number of Labor-initiated inquiries, commissions and authorities.
As the Canberra grapevine identified the descending blades, all manner of interested groups hurriedly sought ways of protecting their areas of interest and influence. Some lost their heads in the scramble, partly for want of comprehending the conservative mind now in power. The leaders of the scientific community, though, were by then well versed in political techniques, and their burst of frenetic activity had considerable, possibly long-lasting, effect.

\section{ASTEC survives-just}

In the eyes of the scientific lobbyists, the principal institution to defend was the fledgling Interim Australian Science and Technology Council 